\title{
Space station survives test of Congress' political will
}

Washington. The international space station has begun its annual voyage through the US budget process with a show of support from House Republicans, whose solid backing seems likely to give the project its easiest ride through Congress for several years.

Last week, the House space and aeronautics subcommittee, chaired by James Sensenbrenner (Republican, Wisconsin), overwhelmingly approved a multi-year, \$13billion authorization bill which, although unlikely to pass into law, will send a clear signal of Congress's intention to see the controversial project through to the end.

The subcommittee rejected, by 18 votes (Democrat, Indiana) to kill the space station. Almost all the subcommittee Republicans are freshmen and enthusiastic budget-cutters. But under the watchful eyes of Sensenbrenner and Bob Walker (RepubCommittee, all of them backed the bill and opposed the Roemer amendment.

Ralph Hall (Democrat, Texas), ranking minority member of the subcommittee and a strong supporter of the station, warned Sensenbrenner of the risk of bringing such a bill to the House floor "in the current climate". But given the solid support of Newt Gingrich (Republican, Georgia) and other Republican House leaders, and the strong party discipline of their troops, most observers see little risk in such a vote this summer. The station retains the strong support of the Clinton administration and of most senators. to 3, an amendment from Tim Roemer lican, Pennsylvania), chair of the Science

George Brown (Democrat, California), ranking minority member of the Science Committee, says he will continue to push for some protection of the total budget of the National Aeronautics and Space Administration (NASA) in exchange for his support of the multi-year authorization bill. But his supporters concede he has little leverage to pursue his goal.

The authorization bill proposes that US funding for the space station should remain constant at $\$ 2.1$ billion a year within an overall NASA budget which, under the House budget resolution (see Nature 375, 168; 1995 ), will fall from $\$ 14.5$ billion this year to $\$ 11.7$ billion by the year 2000 .

During the subcommittee debate, many justifications were put forward for the space station. Hall asserted it was "the only hope" for "people wasting away with cancer in hospitals". Dave Weldon (Republican, Florida) sought biblical inspiration for the station, quoting the biblical proverb that "where there is no vision, the people perish", while Steve Stockman (Republican, Texas), made the more straightforward argument that his wife was employed on the project.

The reality is that Boeing's contract to build the US portion of the station will result in much of the work being strategically placed in hard-pressed aerospace facilities in Texas and California. Neither political party is going to take that work away in the run-up to a presidential election, and the international partners concerned about the US's commitment can sleep soundly at nights.

Colin Macilwain

\section{Two satellites prove better than one}

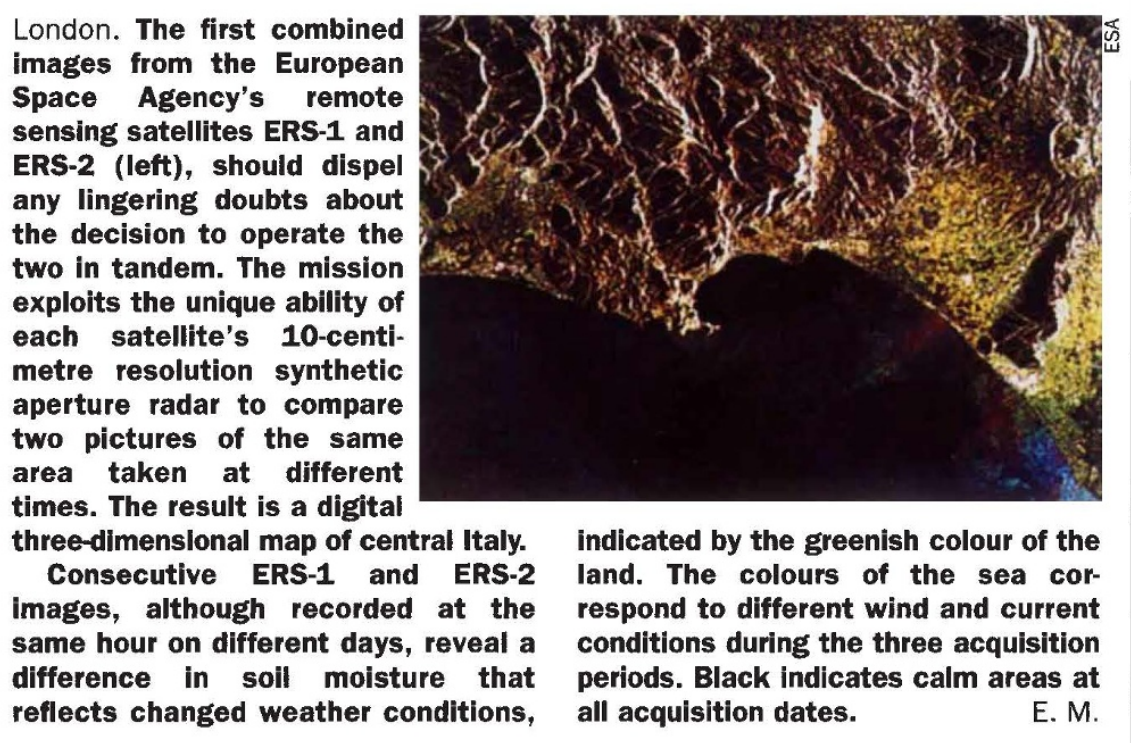

\section{Scripps agrees to revised plan for ocean experiment}

San Diego. The California Coastal Commission is meeting in Carmel today (15 June) to decide whether to approve the Californian part of a controversial project designed to study whether sound waves can be used to measure global warming in the ocean.

The chances of approval have been increased by an agreement last week between the Scripps Institution of Oceanography in San Diego and a number of environmental groups to turn the $\$ 35$ million project into a two-year research programme that will initially concentrate on the effects of sound on marine mammals and only incidentally collect climate data.

Full-scale climate studies would begin only after an environmental review. The shift in emphasis follows concern expressed by environmentalists that the experiment, originally planned purely as way of using the speed of sound through water to measure ocean water temperature, might damage marine animals.

The experiment is known as Acoustic Thermometry of Ocean Climate (ATOC), and will be carried out by an international team of scientists headed by Walter Munk at Scripps. It involves using two transducers in about 1,000 metres of water - one off the coast of northern California, and another off the Hawaiian island of Kauai - to send out coded signals lasting about 20 minutes.

ATOC was supposed to start last year with one transducer in Monterey Bay, a national marine sanctuary. But in March, following criticism from environmentalists, Scripps reduced the planned number of emissions, and moved the transducer to the slopes of a dormant undersea volcano 89 kilometres off the coast.

The new schedule of experiments has now been approved by organizations such as the Environmental Defense Fund, the Natural Resources Defense Council (NRDC) and the Sierra Club Legal Defense Fund. Ann Notthoff of NRDC says the new project is entirely different from that first proposed. "This is now bona fide marine mammal research," she says. "Marine mammologists now control the sound source for two years."

But other organizations still object. "The only thing that has changed is that they call it an extended marine mammal research programme when it isn't," says Ray Chuan, of the Kauai Friends of the Environment.

Although they will be primarily gathering data on the effects of the sounds on marine mammals, researchers will also begin collecting data on water temperatures. "It is not optimized for our work," said Andrew Forbes, the project director. "But we will certainly get some good data." Joel Shurkin 